\title{
MAKNA REFERENSIAL PADA KRITIKAN DI SITUS NGOMIKMAKSA DAN RELEVANSINYA SEBAGAI BAHAN AJAR DI SMA
}

\author{
Tivany Inggar Priatmie dan Atiqa Sabardila \\ Program Studi Pendidikan Bahasa Indonesia \\ Fakultas Keguruan dan Ilmu Pendidikan \\ Universitas Muhammadiyah Surakarta \\ atiqa.sabardila@ums.ac.id \\ tivanyinggar41@gmail.com
}

\begin{abstract}
ABSTRAK
Penelitian ini bertujuan untuk mendeskripsikan makna referensial pada situs Ngomikmaksa, mengetahui penggambaran kritikan pada situs Ngomikmaksa, dan mengetahui relevansi hasil penelitian sebagai bahan ajar pembelajaran bahasa Indonesia di SMA. Pengumpulan data menggunakan teknik dokumentasi dan teknik catat. Metode yang digunakan untuk analisis data adalah metode padan intralingual subjenis referensial dengan teknik lanjutan teknik Pilah Unsur Penentu (PUP). Yang kedua dianalisis dengan padan ekstralingual dengan teknik lanjutan menyamakan hubung banding sesuatu (HBPS); yang ketiga dianalisis dengan analisis perbandingan tetap. Berdasarkan hasil penelitian, disimpulkan bahwa makna referensial dalam kritikan di situs Ngomikmaksa berupa wujud acuan, yaitu iconic sinsign, ikon argumentasi, iconic legsign, rhematic indexical sinsign, rhematic indexical legsign, dicent indexial legsign, rhematic symbol, dicent symbol, dan simbol tanda baca. Dari hasil analisis tersebut dapat diketahui bahwa acuan atau tanda yang paling banyak digunakan dalam adalah iconic sinsign. Makna keseluruhan dari data yang terkumpul adalah pembicaraan peristiwa di Indonesia yang dianggap sangat timpang atau tidak adil. Hal ini dilakukan melalui peragaan tokoh-tokoh besar yang ada di Indonesia, yaitu presiden, pendiri partai, menteri, artis, gubernur, situ ojek online, dan pegawai honorer. Tokoh-tokoh tersebut menjadi perhatian masyarakat dalam kurun waktu terdekat ini. Berkaitan dengan pembelajaran kritikan (teks anekdot) dalam Bahasa Indonesia disimpulkan bahwa bahasa yang santun dipakai saat memberikan sebuah kritikan. Hal itu dibuktikan dengan contoh yang telah diberikan pada situs Ngomikmaksa yang mendorong siswa memahami etika dalam memberikan kritikan, seperti penggunaan alasan yang logis, keharusan penggunaan bahasa yang santun, dan mengajak pembaca memikirkan solusi.
\end{abstract}

Kata Kunci: makna referensial, kritikan, bahan ajar.

\begin{abstract}
This study aimed to describe the referential meaning Ngomikmaksa sites, knowing depiction Ngomikmaks a criticism on the site, and determine the relevance of research results as teaching material in high school learning Indonesian. Collecting data using techniques of documentation and technical notes. The method used to analyze data is unified method intralingual subtype referential with advanced engineering techniques Pilah Element Qualifier (PUP), the second match ekstralingual data analysis with advanced technique appeal something equalizing circuit (HBPS), and the third using constant comparison analysis techniques. According to the research, there are three
\end{abstract}


conclusions: based on the results of research on the meaning refrensial in his criticism on the site Ngomikmaksa there is some form of reference, namely the iconic sinsign, icon argument, iconic legsign, rhematic indexical sinsign, rhematic indexical legsign, dicent indexial legsign, rhematic symbol, dicent symbol, and punctuation symbols. From the analysis, it is known that the reference or the sign of the most widely used is the iconic sinsign. The overall meaning of all the data that has been collected is to discuss the events in Indonesia which is considered very unbalanced or unfair. Through the demonstration of the great figures in Indonesia, namely the president, the founder of the party, ministers, artists, governors, where motorcycles online, and permanent employees. All these figures are figures that became the center of public attention in the nearest period. Relations in learning criticism (text anecdotes) in Indonesian can be concluded that the use of polite language when giving a criticism. This was evidenced by the examples given on the site Ngomikmaksa encourage Shiva understand ethics in providing such criticism, using a logical reason, the language must be polite, and invites the reader to think of a solution.

Keywords: referential meaning, criticism, teaching materials.

\section{PENDAHULUAN}

Komunikasi adalah hal yang tidak bisa dihindarkan oleh setiap manusia. Saat berkomunikasi, ada hal yang terpenting, yaitu media. Melalui media, semua informasi bisa sampai kepada masyarakat. Bukan tidak mungkin banyak orang di zaman modern ini mengenal media, baik itu media cetak, tulis, maupun elektronik.

Secara tidak langsung, dalam berkomunikasi, akan terjadi proses interaksi antara penutur dengan mitra tuturnya. Ini bisa terjadi pada informasi lisan atau pun non lisan. Informasi non lisan bisa terjadi pada sebuah wacana. Proses interaksi dalam sebuah wacana terjadi pada jurnalis (penulis berita) dengan pembacanya. Hal tersebut dikarenakan informasi yang disampaikan oleh penulis berita adalah hasil gagasan-gagasnnya dan mengandung makna tersendiri. Selain berfungsi untuk menyampaikan informasi, media bisa dijadikan sebagai sarana hiburan. Fungsi media sebagai hiburan bisa dilihat banyak karya yang diciptakan oleh orang melalui karikatur, komik, atau pun animasi. Komik secara umum adalah cerita bergambar dalam majalah, surat kabar, atau buku yang pada umumnya mudah dicerna dan lucu (Sobur, 2013:137). Adapun gambar lelucon yang membawa pesan kritik sosial sebagaimana dapat dilihat di setiap ruang opini surat kabar disebut dengan karikatur (Sobur, 2013:138).

Seiring dengan perkembangan zaman, media tersebut dijadikan wadah sebagai bahan untuk menyampaikan kritikan. Kini orang menjadi lebih kreatif dalam menyampaikan aspirasinya. Tidak hanya melakukan demonstrasi di jalan dan membuat tulisan-tulisan, akan tetapi banyak orang menggunakan media berupa media bergambar. Berkembangnya zaman sekarang media bergambar tidak hanya digunakan sebagai hiburan bagi anak-anak, tetapi bertambah fungsinya untuk beropini dengan situasi yang mereka hadapi. Melalui media tersebut, karikatur menggunakan kreativitas dengan menambahkan gambar-gambar yang mendukung dengan apa yang coba diutarakan. Walaupun menggunakan kata-kata yang minim, karikatur mencoba menggunakan kata-kata yang padat, tidak berbelit-belit dan jelas bagi pembacanya.

Banyak orang beropini mengenai masalah sosial, politik, pendidikan, ekonomi, dan lainlain. Dalam memaknai sebuah media bergambar tidak hanya melihat apa yang terdapat pada gambar tersebut. Media bergambar tersebut dibuat bisa dihubungkan dengan kondisi atau pun situasi yang sedang diperbincangkan pada masyarakat di suatu wilayah. 
Banyak media bergambar yang digunakan sebagai ruang beropini, antara lain kartun, karikatur, komik, dan anekdot. Melalui pendapat para penulis menyampaikan pesan dengan cara tersirat maupun tersurat kepada pembacanya. Makna tersebut harus diketahui oleh pembaca dengan berbekal pengetahuan yang dimilikinya. Setiap tanda (sign) selalu merupakan perpaduan yang tak terpisahkan antara bentuk (penanda) paduan yang terpisahkan antara aspek bentuk (penanda) dan aspek arti (petanda) (Subroto, 2011:3). Pembaca yang baik harus bisa menghubungkan kritikan tersebut dengan yang dimaksudkan oleh kritikus dengan situasi yang ada. Setiap makna pula pastilah mempunyai acuan agar dapat dimengerti.

Wacana humor biasanya terbentuk oleh sebuah kata yang tidak semestinya. Unsur bahasa yang digunakan tidak menggunakan kaidah kebakuan. Inilah yang membuat seseorang tidak jenuh membacanya karena menimbulkan hal yang menarik. Banyak wacana humor menimbulkan gelak tawa bagi pembacanya.

Kritikan yang telah dibuat biasanya diterbitkan bukan hanya melalui media cetak, melainkan juga melalui elektronik. Banyak situs yang memuat kartun, karikatur, dan anekdot berisi kritikan. Kurikulum 2013 pun mengajarkan siswa dalam memberikan kritikan. Ini tertuang dalam mata pelajaran Bahasa Indonesia yaitu teks anekdot. Dalam dunia pendidikan seorang siswa juga harus bisa memberikan kritikan yang baik dan santun. Hal ini dikarenakan seorang yang berpendidikan harus bisa berbahasa yang baik dan santun, bahkan dalam memberikan kritikan sekalipun.

Dalam penelitian ini dipilih situs Ngomikmaksa untuk dijadikan sebagai sumber penelitian. Hal ini dikarenakan situs tersebut memuat berbagai tema tidak hanya terfokus pada tema tertentu. Hal lain yang melatarbelakangi peneliti adalah topik yang dipilih pada situs tersebut lebih kekinian.

Berdasarkan latar belakang yang telah diuraikan, ada tiga rumusan masalah dalampenelitian, yaitu bagaimana makna referensial pada situs Ngomikmaksa, bagaimana penggambaran kritikan pada situs Ngomikmaksa, dan bagaimana relevansi hasil penelitian sebagai bahan ajar pembelajaran bahasa Indonesia di SMA?

Tujuan penelitian yang ingin dicapai adalah mendeskripsikan makna referensial pada situs Ngomikmaksa, mengetahui penggambaran kritikan pada situs Ngomikmaksa, dan mengetahui relevansi hasil penelitian sebagai bahan ajar pembelajaran bahasa Indonesia di SMA.

Penelitian ini diharapkan dapat memberikan pengetahuan yang berhubungan dengan makna referensial atau ilmu tentang makna dalam sebuah kritikan. Selain itu, penelitian ini dapat memberikan sumbangan pengetahuan dalam memahami sebuah makna. Bagi seorang pendidik penelitian ini dapat dijadikan sebagai bahan ajar dalam pembelajaran Bahasa Indonesia dibidang bahasa, khususnya pembelajaran mengenai teks anekdot serta etika dalam membuat sebuah kritikan.

\section{METODE PENELITIAN}

Jenis penelitian ini adalah penelitian kualitatif. Penelitian kualitatif adalah suatu penelitian yang ditujukkan untuk mendeskripsikan dan menganalisis fenomena, peristiwa, akativitas sosial, sikap, kepercayaan, persepsi, dan pemikiran orang secara individual atau kelompok (Sukmadinata, 2009:60). Penelitian ini berbentuk deskriptif kualitatif karena bertujuan untuk menggambarkan atau mendeskripsikan makna referensial di situs Ngomikmaksa.

Data adalah sebagai fenomena lingual khusus yang mengandung dan berkaitan langsung dengan masalah yang dimaksud, (Sudaryanto, 2015:6). Data pada penelitian ini adalah tulisan yang dapat digali makna referensialnya pada situs Ngomikmaksa serta hubungan dalam etika memberikan kritikan yang baik, yang mempunyai konteks dalam wacana tersebut. Sumber data situs Ngomikmaksa. 
Metode pengumpulan data berupa dokumentasi dan catat. Dokumen-dokumen yang dihimpun dipilih yang sesuai dengan tujuan dan fokus masalah (Sukmadinata, 2009:222). Dokumentasi dalam penelitian ini berupa pengumpulan karikatur-karikatur yang ada pada situs Ngomikmaksa. Teknik pengumpulan data ini dilanjutkan dengan teknik catat. Teknik ini dilakukan dengan pencatatan ke dalam bentuk tulisan terhadap pokok permasalahan yang akan diteliti kemudian diklasifikasikan.

Teknik analisis data menggunakan metode padan intralingual dan ekstralingual. Metode padan intralingual kemudian dilanjutkan oleh teknik PUP. Metode padan yang digunakan pada penelitian ini, yakni bagian sub jenis kesatu, yaitu dengan alat penentu referen (Sudaryanto, 2015:15). Metode padan intralingual adalah metode analisis dengan menghubung bandingkan unsur-unsur yang bersifat lingual, baik yang terdapat dalam satu bahasa maupun dalam beberapa bahasa yang berbeda (Mahsun, 2005:118). Teknik ini digunakan untuk menentukan makna referensial. Metode padan dilanjutkan dengan teknik dasar Pilah Unsur Penentu (PUP) dan menggunakan alat berupa daya pilah referensial. Daya pilah ini sesuai dengan jenis-jenis acuan yaitu ikon, simbol, dan indeks.

Teknik analisis data yang kedua adalah metode padan ekstralingual, pada teknik ini akan menghubungkan banding masalah bahasa yang berada di luar bahasa (Mahsun, 2005:120). Teknik analisis kedua menggunakan teknik lanjutan dari pada ekstralingual yaitu teknik hubung banding menyamakan hal pokok (HBSP). Penggunaan teknik ini adalah dengan menghubung bandingkan hal-hal yang menyangkut mengenai kejadian yang berlangsung di masyarakat melalui surat kabar online. Tujuan ketiga menggunakan teknik analisis metode perbandingan tetap, yaitu membandingkan satu datum (informasi) dengan datum yang lain, yang kemudian membandingkan sesuai dengan kategori yang telah ditetapkan. Dalam analisis data diidentifikasi adanya etika mengkritik yang baik sehingga mempunyai keterkaitan dengan SK dan KD. Metode ini juga menganalisis bagaimana konsep tersebut terhadap pembelajaran teks anekdot sehingga diketahui penggunaan bahasa yang santun walaupun saat mengkritik suatu peristiwa.

Data yang telah ada perlu diuji keabsahannya untuk dapat melakukan pengecekan sekaligus sebagai pembanding terhadap kebenaran suatu data. Proses keabsahan dilakukan agar kebenaran terhadap temuan data menghasilkan keakuratan. Teknik yang digunakan untuk proses keabsahan data dikenal dengan triangulasi, yakni teknik pemeriksaan keabsahan data yang memanfaatkan sesuatu yang lain (Meolong, 2014:330).

Denzin (dalam Moleong, 2014:330) membedakan empat macam trianggulasi sebagai teknik pemeriksaan yang memanfaatkan sumber, metode, penyidik, dan teori. Triangulasi yang digunakan dalam penelitian ini adalah triangulasi teori. Triangulasi teori yaitu data yang terkumpul dapat diperiksa derajat kepercayaannya dengan satu atau lebih teori sebagai perbandingan. Pengumpulan dan pengujian data yang berupa makna referensial pada sebuah kritikan yang telah diperoleh dan dianalisis dibandingkan dengan beberapa teori tentang makna referensial yang digunakan oleh peneliti.

\section{HASIL DAN PEMBAHASAN}

\section{Analisis Makna Referensial Kritikan di Situs Ngomikmaksa}

Temuan penelitian disajikan dalam bentuk tema yang sering terjadi di masyarakat. Tematema tersebut meliputi sosial, politik, pendidikan, dan ekonomi. Akan tetapi, dari sekian banyak tema diambil dari tema yang terkini dan paling banyak muncul di situs Ngomikmaksa, yaitu sosial dan politik.

Manoppo (2013) menghasilkan pada periode Habibie, kekuasaan digunakan sebagai alat untuk berlindung dari hukum serta sebagai alat untuk melakukan tindakan kriminal. Para periode 
Gus Dur korupsi diwacanakan sebagai tindakan yang buruk namun tidak ada penanganan terhadap para pelaku korupsi. Dalam pemerintahan Megawati negara Indonesia diwacanakan sebagai negara yang korup. Dalam pemerintahan SBY, pewacanaan korupsi merupakan sebuah kritik terhadap pemerintahan Indonesia yang tidak mampu dalam menangani kasus Soeharto.

Penelitian Hilda (2014) dihasilkan makna bahwa calon anggota legislatif dalam kartun Oom Pasikom digambarkan sebagai sosok yang bodoh, mudah dimanfaatkan, mudah tergiur kekayaan, menghalalkan segala cara untuk mendapatkan keinginan, dan gila kekuasaan.

Pierce membagi tanda menjadi tiga, yaitu ikon, indeks, dan simbol. Berdasarkan hasil penelitian mengenai makna refrensial dalam kritikan di situs Ngomikmaksa terdapat beberapa wujud acuan, yaitu iconic sinsign, ikon argumentasi, iconic legsign, rhematic indexical sinsign, rhematic indexical legsign, dicent indexial legsign, rhematic symbol, dicent symbol, dan simbol tanda baca. Contoh pemakaian tanda di Situs Ngomikmaksa:

1) Waaa!!! (Ikon Deskripsi)

2) Orang yang sedang memakan hamburger menunjukkan rakyat biasa. (Ikon Deskripsi)

3) Wanita berpakaian kantor sebagai pelanggan ojek. (Ikon Deskripsi)

4) Pria memegang payung sebagai penawar ojek payung. (Ikon Deskripsi)

5) Tokoh gubernur Jakarta yaitu AHOK (Icon Sinsign)

6) Pria kemeja biru adalah menteri pendidikan Anies Baswaden(Icon Sinsign)

7) Pria berseragam coklat sebagai guru honorer. (Icon Sinsign)

8) Tokoh dengan jas hitam merupakan gambaran dari Jokowi. (Icon Sinsign)

9) Wanita berbaju merah, tahi lalat di bawah bibir serta memakai kacamata merupakan tokoh Megawati Sukarno Putri. (Icon Sinsign)

10) Lelaki yang kurus dengan rambut cepak, mata sipit adalah Joko Widodo. (Icon Sinsign)

11) Omong doang lu!!!. (Rhematic Indexical Legsign)

12) Saya akan terjun dari sini! (Rhematic Indexical Legsign)

13) Gue bantai lo dan keluarga lo!. (Rhematic Indexical Legsign)

14) Koh!!! (Rhematic Indexical Sinsign)

15) Pria dengan gigi terlihat, jari menunjuk dan garis mulut terlihat jelas menandakan kekesalan. (Rhematic Indexical Sinsign)

16) Boikot produk Israel. (Rhematic Indexical Sinsign)

17) Orang membawa payung menandakan sedang turun hujan dengan deras. (Rhematic Indexical Sinsign)

18) Bacground warna merah dan $W$ menandakan salah satu produk makanan cepat saji di Indonesia. (Dicent Legsign)

19) Aku bisa melakukannya sendiri buk! Ibu jangan nyuruh-nyuruh aku lagi, aku udah dewasa! (Dicent Legsign)

20) Kakak udah order ojek payung dari app. (Dicent Legsign)

21) Tugu monas (menandakan tempat yang tinggi). (Simbol Deskripsi)

22) Kartu biru menandakan KTP. (Rhematic Symbol)

23) Baju merah menandakan partai yang dinaungi tokoh tersebut yaitu PDI P. (Rhematic Symbol)

24) Makan banteng. (Rhematic Symbol)

25) Seragam coklat menandakan anggota PNS atau guru. (Dicent Symbol)

26) W dapat juga dibaca M yaitu kepanjangan dari MC Donald. (Dicent Symbol)

27) Gambar payung di smartphone menandakan situs ojek yang dilakukan secara online. (Dicent Symbol) 
Dari hasil analisis tersebut, dapat diketahui bahwa acuan atau tanda yang paling banyak digunakan dalam adalah iconic sinsign. Penggunaan tanda menurut Pierce dapat dipaparkan lebih jelas pada gambar yang terdapat pada karikatur-karikatur berikut ini:

Edisi 29 Maret 2016:

Ikon :WAAAA! merupakan deskripsi dari sebuah kata untuk mengungkapkan sebuah makna, yakni. Ujaran “waaa” menunjukkan keterkejutan karena sesuatu hal. Dalam peristiwa pada gambar tersebut adalah terjun dari tempat yang tinggi.

Indeks : Omong doang lu!!!. Kata $l u$ berarti orang yang bermulut besar dalam wacana tersebut. Saya akan terjun dari sini!. Objek yang terdapat pada kata dari sini! mengacu pada Tugu Monas.

Simbol :Tugu Monas (menandakan tempat yang tinggi). Gambar yang ada menunjukkan bangunan yang tinggi menjulang dengan emas di atasnya. Adanya gambar dengan benda yang dapat dilihat masyarakat ini menimbulkan asosiasi masyarakat. Bangunan ini adalah suatu tempat di ibukota, yakni sebagai pusat pemerintahan.

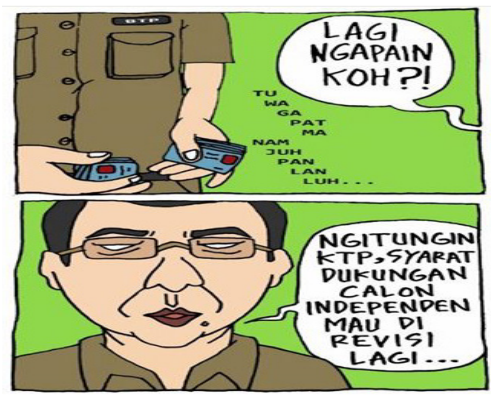

Edisi 16 Maret 2016

Ikon : Tokoh yang memimpin Jakarta, yakni Gubernur DKI Jakarta, Ahok (Basuki Cahaya Purnama).

Indeks : Koh mengacu pada tanda atau acuannya mengandung pengalaman secara langsung yang disebabkan oleh sesuatu hal. Sapaan "KOH" merupakan panggilan untuk orang yang berdarah Tionghoa seperti yang ditujukkan untuk Ahok.

Simbol : Kartu biru menandakan KTP tanda yang menghubungkan objek dan penafsiran bersifat umum. Tanda tersebut adalah KTP sebagai objek yang menjadi sorotan pada wacana tersebut.

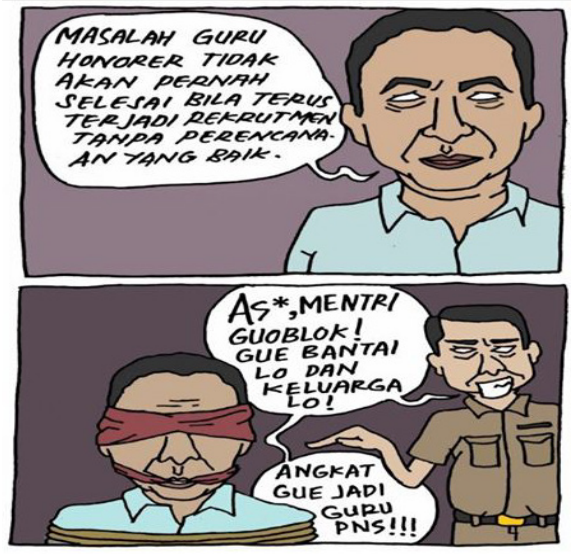

Edisi 15 Maret 2016 
Ikon : Pria berkemeja biru adalah Menteri Pendidikan Anies Baswaden, sedangkan pria berseragam coklat sebagai guru honorer.

Indeks : Pria dengan gigi terlihat dengan jari menunjuk, serta ada garis pada mulutnya menandakan kekesalan. Hal itu merujuk pada tanda atau acuannya mengandung pengalaman secara langsung yang disebabkan oleh sesuatu hal yaitu ekspresi kekesalan. Gue bantai lo dan keluarga lo!. Tuturan itu mengacu pada objeknya, yaitu kata gue yang ditujukkan pada pegawai honorer dan lo untuk Menteri Pendidikan, Anies Baswaden yang sedang diikat oleh seseorang.

Simbol : Seragam coklat menandakan anggota PNS atau guru

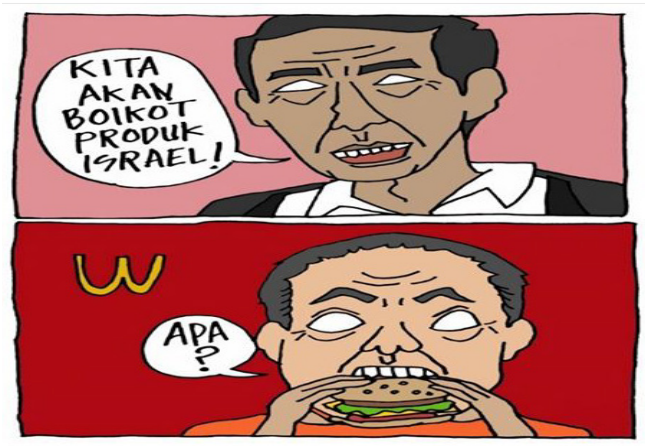

Edisi 10 Maret 2016

Ikon : Tokoh dengan jas hitam adalah gambaran dari Presiden Jokowi. Adapun orang yang sedang memakan Hamburger menunjukkan gambaran dari rakyat biasa.

Indeks : Background warna merah dan $\mathrm{W}$ menandakan salah satu produk makanan cepat saji di Indonesia. Boikot produk Israel (produk Israel seperti senjata, makanan, dan minuman). Amerika adalah negara yang bersekutu dengan Israel. Dikhawatirkan akan menyumbangkan pendapatan tersebut untuk Isreal, yang notabene-nya selalu membuat kekacauan dunia.

Simbol : W (jika dibalik) dapat juga dibaca M yaitu kepanjangan dari MC Donald.

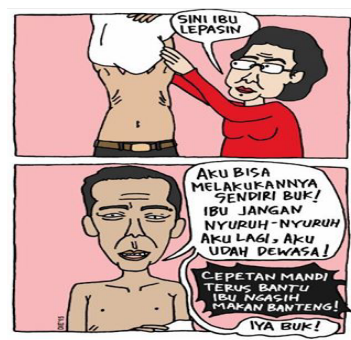

Edisi 20 Oktober 2015

Ikon : Wanita berbaju merah dengan tahi lalat di bawah bibir serta memakai kacamata mengacu tokoh Megawati Sukarno Putri. Adapun lelaki yang kurus dengan rambut cepak dengan mata sipit adalah Joko Widodo

Indeks : Aku bisa melakukannya sendiri, Buk! Ibu jangan nyuruh-nyuruh aku lagi, aku udah dewasa!. Aku yang dimaksudkan adalah presiden Joko Widodo, yang selalu dikaitkan menjadi pesuruh partai (: ptugas partai). Pada ujaran "aku udah dewasa" mempunyai makna kalau ia (Joko Widodo) adalah seorang presiden, yaitu orang nomor satu di Indonesia. Jadi, segala tindakannya bukan dari partai. Dia tidak disetir pemimpin partai.

Simbol : Baju merah menandakan partai yang dinaungi tokoh tersebut, yaitu PDIP. 
Makan banteng menunjukkan partai PDIP karena partai tersebut mempunyai logo kepala banteng.

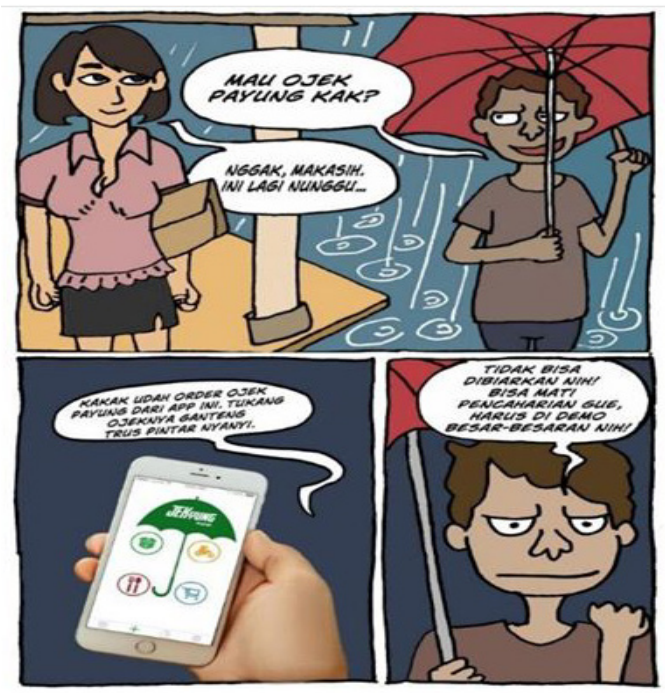

Edisi 23 Maret 2016

Ikon : Wanita berpakaian kantor sebagai pelanggan ojek, sedangkan pria yang memegang payung sebagai penawar ojek payung.

Indeks : Orang membawa payung menandakan sedang turun hujan dengan deras. Kakak udah order ojek payung dari app. Tuturan tersebut diartikan sebuah kecemburuan dari ojek langsung dan ojek online yang heboh akhir-akhir ini. Penumpang lebih percaya dengan ojek online karena keamanannya dibandingkan dengan ojek langsung.

Simbol : Gambar payung di smartphone menandakan situs ojek yang dilakukan secara online.

\section{Pemaknaan Kritikan di Situs Ngomikmaksa}

Pemaknaan kritikan terhadap contoh yang telah dianalisis kemudian dihubungkan dengan surat kabar online. Kegiatan menghubungkan ini dilakukan untuk mengetahui derajat kebenaran dan ketepatan penafsiran makna yang telah dianalisis oleh peneliti dengan situasi masyarakat.

$\mathrm{K} 1$ adalah orang yang mempunyai sifat besar mulutnya. Artinya, dia selalu berkoar-koar menentang peraturan yang dia tidak sukai. Dia juga ingin melakukan sesuatu di luar akal, akan tetapi itu semua hanyalah bualan. Alangkah baiknya aktivitas verbal itu diikuti dengan tindakan yang rasional. Ini sebagai bukti bahwa peraturan pemerintah itu sangat memberatkan warganya.

Pembuktian lain dapat dilihat dari koran online pada Tempo bahwa kritikan tersebut mengungkapkan keberatan terhadap kenaikkan pembayaran BPJS.

TEMPO.CO, Jakarta-Kepala Humas Badan Penyelenggara Jaminan Sosial Kesehatan Irfan Humaidi mengatakan iuran peserta mandiri atau pekerja bukan penerima upah (PBPU) mengalami kenaikan. Kenaikan tersebut berlaku per 1 April 2016.

"Iuran peserta mandiri BPJS Kesehatan mengalami perubahan sebagaimana tertuang dalam peraturan presiden yang baru diterbitkan. Masyarakat diharapkan dapat membacanya," katanya saat dihubungi. Tempo, Sabtu, 12 Maret 2016.

Dengan terbitnya perpres itu, besaran iuran kelas I yang semula Rp 59.500 menjadi Rp 80 ribu. Iuran kelas II yang semula Rp 42.500 naik menjadi Rp 51 ribu. Sedangkan 
iuran kelas III yang semula Rp 25.500 menjadi Rp 30 ribu.

Sumber : Tempo.com

K2 dapat dimaknai bahwa gubernur Jakarta yang sedang berkuasa sedang mengumpulkan KTP dari warganya demi menunjukkan kepuasan terhadap hasil kerjanya selama ini. Ini dilakukan karena banyak yang menentang akan peraturan-peraturan yang dibuatnya yang dinilai merugikan pejabat yang tidak bekerja serius. Bukti pendukung bahwa kritikan tersebut mengenai bela Ahok terdapat pada surat kabar online Detik.com sebagai berikut.

Jakarta - KTP dukungan untuk pasangan bakal cagub-cawagub DKI Ahok-Heru terkumpul dengan cepat. Relawan Teman Ahok menggelar syukuran karena sudah berhasil mengumpulkan 532 ribu KTP, jumlah minimal untuk mendaftar Pilgub DKI 2017 lewat jalur independen.

"Tanggal 11 Maret kami mulai efektif melakukan pengumpulan ulang dukungan formulir baru, dan sekarang tepat 1 bulan sudah terkumpul 533.420 fotokopi KTP dan formulir dukungan," ujar Juru Bicara Teman Ahok Amalia Ayuningtyas di sekretariat Teman Ahok Graha Pejaten, J1 Pejaten Raya, Jakarta Selatan, Senin (11/4/2016).

Sumber: Detik.com

K3 menggambarkan seorang menteri saat mengangkat PNS yang harus sesuai dengan rencana dan prosedur yang baik. Akan tetapi, hal tersebut tidak diimbangi guru honorer yang menginginkan untuk diangkat PNS dengan mudah. Bukti yang menyatakan dengan realita bahwa kritikan tersebut mengenai guru honorer yang tidak diperhatikan terdapat pada surat kabar online Republika.

Republika.co.id, Jakarta -- Forum Honorer Kategori Dua Indonesia (FHK2I) harus menelan 'pil pahit' setelah melakukan pertemuan dengan Menteri Pendayagunaan Aparatur Negara dan Reformasi Birokrasi (MenpanRB), Yuddy Chrisnandi.

Pertemuan yang dilakukan Kamis (4/2) kemarin, tidak memberikan hasil sesuai yang diharapkan terkait pengangkatan ratusan guru honorer K2. Padahal, pemerintah sudah berjanji akan mengangkat mereka.

K4 mengungkapkan sebuah wacana untuk menghindari produk Israel karena negara tersebut adalah negara yang mencerminkan tidak menyukai kedamaian. Akan tetapi, banyak kalangan menganggap pula bahwa produk makanan Mcdonal sebagai salah satu dari Israel. Padahal MC Donald berasal dari Amerika. Mereka menilai bahwa kedua negara tersebut bersekutu.

Liputan6.com, Jakarta - Juru Bicara Presiden Johan Budi SP membantah Presiden Jokowi menyerukan seluruh negara-negara yang tergabung dalam Organisasi Kerja Sama Islam (OKI) memboikot segala produk dari Israel. Menurut Johan, maksud Jokowi adalah memboikot produk kebijakan Israel yang secara sepihak menduduki tanah Palestina.

"Jadi saya melihat, ini dimaknai sebagai produk barangnya Israel yang diboikot kan, sebenarnya bukan. Boikot dalam hal ini adalah hal-hal yang berkaitan dengan kebijakan Israel yang berada di tanah pendudukan Palestina," ujar Johan di Istana Kepresidenan, Jakarta, ditulis Rabu (9/3/2016). 
K5 mengungkapkan makna seorang presiden yang selalu menurut pada pendiri partai PDIP. Seharusnya sebagai pemimpin negara tidak boleh menurut pada partai yang mengusungnya, akan tetapi harus bisa melakukan tindakan sendiri. Bukti berita yang mennyangkut pemberitaan tentang Jokowi yang dianggap sebagai pesuruh partai terdapat pada surat kabar online Liputan6. com.

Liputan6.com, Sanur - Istilah petugas partai sempat disematkan kepada para kader Partai Demokrasi Indonesia Perjuangan (PDIP) yang duduk di pemerintahan, termasuk Presiden Jokowi. Karena terkesan berkonotasi negatif, Ketua Umum DPP PDIP Megawati Soekarnoputri pun meluruskan istilah tersebut.

"Petugas partai jangan dikonotasikan sebagai pesuruh, tapi mau ditempatkan di mana saja, itu konsekuensi. Tapi kadang ada yang tak mau," ujar Megawati di arena Kongres IV PDIP di Inna Grand Bali Beach Hotel, Sanur, Bali, Jumat (10/4/2015). Sumber: Liputan6.com

K6 menceritakan para pengendara ojek sedang diresahkan karena kehadiran ojek online. Mereka khawatir kalau mata pencaharian akan terkalahkan dengan pengguna ojek online, apalgi pelanggan lebih mempercayai ojek online karena faktor keamanan mereka. Bukti mengenai permasalahan antara pengendara ojek dan jasa ojek online terdapat pada Detik.com.

Jakarta - Menteri Perhubungan Ignasius Jonan angkat bicara untuk meluruskan tudingan diskriminasi perlakuan antara ojek online dengan ojek pangkalan. Menurutnya, ini yang membedakan antara keduanya.

"Aplikasi online itu sistem reservasi. Sementara ojek pangkalan selalu dianggap sebagai kegiatan non-transportasi publik," kata Jonan kepada detikINET, Jumat $(18 / 12 / 2015)$.

\section{Hubungan Kritikan di Situs Ngomikmaksa sebagai Bahan Ajar}

Gaines (2006) memaparkan bahwa dalam kehidupan sehari-hari ruang jarang dipertimbangkan untuk kualitas independen, tetapi lebih umum diambil sebagai kategori konsepsi yang bertindak sebagai latar belakang atau konteks makna yang benda lainnya. Studi ruang sebagai fenomena semiotik menunjukkan bahwa makna ruang, sebagai tanda, umumnya dipahami dalam kaitannya dengan masalah lain. Komunikasi menarik perhatian konten pesan sementara ruang kontribusi terhadap makna dari pesan tersebut tanpa jelas tentangnya peran dalam membangun makna. Persamaan penelitian yang dilakukan oleh Gaines dengan penelitian ini adalah keduanya mengungkapkan perannya tanda untuk mengungkapkan sebuah makna. Perbedaanya terletak pada penelitian Gaines hanya bersifat kebahasaan dan tidak mempunyai keterkaitan sebagai bahan ajar di sekolah.

Kritikan yang yang terdapat pada situs Ngomikmaksa mempunyai hubungan dengan pembelajaran. Cartoon editorial. Dengan demikian, dapat dijadikan bahan ajar SMA kelas X semester 1 yang digunakan pada kurikulum 2013. Materi yang tepat dijadikan sebagai bahan ajar adalah teks anekdot. Keterkaitan kritikan di situs Ngomikmaksa dengan pembelajaran teks anekdot merujuk pada Kompetensi Dasar (KD) pada kurikulum 2013 yaitu :

1) Mensyukuri anugerah Tuhan akan keberadaan bahasa Indonesia dan menggunakannya sebagai sarana komunikasi dalam mengolah, menalar, dan menyajikan informasi lisan dan tulis melalui teks anekdot.

2) Menunjukkan sikap tanggung jawab, peduli, responsif, dan santun dalam menggunakan bahasa Indonesia untuk membuat anekdot mengenai permasalahan sosial, lingkungan, dan kebijakan publik 
Pada KD 1.2 dan 2.1 tersebut jelas data dan sumber data yang telah dikumpulkan mempunyai keterkaitan dengan pembelajaran bahasa Indonesia. Teks anekdot itu sendiri berkaiatan sebagai sarana komunikasi untuk menyampaikan pendapatnya. Peserta didik juga akan diajarkan untuk mempunyai sifat-sifat yang terdapat pada KD 2.1, yaitu tanggung jawab, peduli, responsif, dan santun dalam menggunakan bahasa. Konteks santun dalam menggunakan bahasa bisa diartikan juga sebagai etika dalam memberikan kritikan.

Dalam materi teks anekdot ini dapat dijadikan implementasi dalam pembelajaran bahasa Indonesia. Apalagi dalam penulisan anekdot selain memperhatikan strukturnya juga harus memperhatikan etika dalam memberikan kritikan. Teks anekdot itu berisi mengenai kritikan yang terjadi di masyarakat yang disampaikan dari bahasa lisan atau pun tulisan.

Karikatur yang tidak tepat untuk dijadikan bahan ajar adalah karikatur 3 karena terdapat kata-kata ungkapan seperti menyamakan manusia dengan binatang. Walaupun tidak ditulis secara lengkap, kata-kata yang dipilih menggunakan kata-kata yang kasar. Orang mengkritik harus menggunakan bahasa yang halus, tatapi mengena maknanya.

Bahan ajar media yang digunakan oleh pendidik dalam menyampaikan apa yang akan diberikan oleh peserta didik. Kualitas bahan ajar itu perlu dipertimbangkan demi kualitas terhadap suatu materi. Hal serupa juga berlaku pada materi teks anekdot. Teks ini berisi kritikan yang coba disampaikan oleh penulis kritikan terhadap suatu kejadian yang terjadi di masyarakat. Adapun kualitas bahan ajar yang perlu diperhatikan dalam penelitian ini sebagai berikut. Ini berdasarkan pemikiran logis

Peserta didik perlu diberikan penjelasan dari umum ke khusus. Artinya, siswa akan diajak memeperhatikan hal-hal yang ada di sekitar mereka. Peserta didik kemudian mulai untuk mencerna kejadian tersebut yang bersangkutan dengan pelajaran. Pembuatan anekdot bisa dijadikan contoh nyata dalam pembelajaran. Siswa akan diajak untuk melihat peristiwa sekitar yang bisa dijadikan kritikan (pembuatan teks anekdot). Pemikiran logis yang lebih luas perlu dilakukan agar bisa mengembangkan pembuatan anekdot.

Bahan ajar yang dipaparkan secara tidak logis akan menyulitkan peserta belajar. Siswa akan diajak untuk mengetahui bahkan membaca koran yang dapat menjadi teks anekdot. Logika dalam penyajian ini merupakan alat bantu yang menjelaskan hubungan antar topik yang terdapat pada bahan ajar tersebut. Dengan demikian, informasi yang diterima oleh peserta akan saling mendukung dengan informasi yang sudah dimiliki sebelumnya.

\section{a. Materi harus Jelas}

Materi yang disajikan perlu diperhatikan. Dalam pembuatan teks anekdot perlu diperhatikan struktur anekdot. Peserta didik yang telah memahami struktur anekdot kemudian beralih dalam pembuatan teks anekdot. Anekdot berisi mengenai kritikan artinya peserta didik perlu memperhatikan etika dalam menggunakan kritikan.

\section{b. Penggunaan Bahasa}

Penggunaan bahasa adalah hal terpenting untuk pemahaman sebuah infromasi. Bahasa yang digunakan haruslah singkat, padat, jelas, serta tidak berbelit-belit. Pembuatan anekdot perlu menggunakan bahasa yang menarik. Tidak perlu menggunakan bahasa yang terikat (formal). Bahasa yang digunakan mempunyai maksud tertentu. Pemilihan bahasa non formal demi menghindari kebosasan bagi pembaca. Penggunaan kata yang berkonotasi juga perlu digunakan agar peserta didik menguasai berbagai kosakata. Etika mengkritik sebuah peristiwa yang dapat dijadikan teks anekdot dapat dipaparkan sebagai berikut: (1) alasan logis tidak mengada-ada, (2) menggunakan bahasa yang santun, dan (3) terdapat sebuah solusi. 
Dalam mengkritik sesuatu informasi atau kejadian seseorang harus memberikan katakata yang logis sehingga dapat diterima oleh akal dan tidak terkesan mengada-ada. Meskripun menyampaikan kritikan, orang tidak boleh melupakan bahasa yang santun. Penggunaan bahasa harus menghindari kata-kata kotor, tidak menyebutkan manusia dengan hewan dan menggunakan makna kiasan. Kritikan tersebut meminimalisasi terjadinya kesalahpahaman. Di dalam mengkritik harus disertakan solusinya. Walaupun tidak secara jelas tertulis dalam teks tersebut, penulis karikatur harus bisa mengajak pembaca memikirkan solusi terhadap permasalahan yang dibicarakan

\section{SIMPULAN}

Berdasarkan hasil analisis makna referensial pada kritikan di situs Ngomikmaksa diperoleh simpulan sebagai berikut. Berdasarkan hasil penelitian mengenai makna refrensial dalam kritikan di situs Ngomikmaksa terdapat beberapa wujud acuan, yaitu iconic sinsign, ikon argumentasi, iconic legsign, rhematic indexical sinsign, rhematic indexical legsign, dicent indexial legsign, rhematic symbol, dicent symbol, dan simbol tanda baca. Dari hasil analisis tersebut dapat diketahui bahwa acuan atau tanda yang paling banyak digunakan dalam adalah iconic sinsign. Makna keseluruhan dari seluruh data yang telah terkumpul adalah pembicaraan tentang peristiwa di Indonesia yang dianggap sangat timpang atau tidak adil melalui peragaan tokoh-tokoh besar yang ada di Indonesia, yaitu presiden, pendiri partai, menteri, artis, gubernur, situ ojek online, dan pegawai honorer. Semua tokoh tersebut merupakan yang menjadi pusat perhatian masyarakat dalam kurun waktu terdekat ini.

Berkaitan dengan hubungan dalam pembelajaran kritikan (teks anekdot) dalam Bahasa Indonesia dapat disimpulkan bahwa pemakaian bahasa yang santun saat memberikan sebuah kritikan. Dibuktikan dengan contoh yang telah diberikan pada situs Ngomikmaksa mendorong siswa memahami etika dalam memberikan kritikan seperti, menggunakan alasan yang logis, bahasa harus santun, dan mengajak pembaca memikirkan solusi.

\section{DAFTAR PUSTAKA}

Djajasudarma, Fatimah. 2012. Semantik 1 Makna Leksikal dan Gramatikal. Bandung: PT Refika Aditama.

Gaines, Elliot. 2006. "Communication and the Semiotics of Space". Journal of Creative Communications. Volume 1, Nomor 2, Halaman 173-181.

Hilda, Mufida, 2014, "Penggambaran Calon Anggota Legislatif Pemilihan Umum 2014 pada Kartun Editorial Harian Kompas". Commonline Departemen Komunikasi. Volume 4, Nomor 1, Halaman 111-120.

Mahsun. 2005. Metode Penelitian Bahasa: Tahapan Strategi, Metode, dan Tekniknya Pengarang. Jakarta: PT Raja Grafindo Persada.

Manoppo, Romario Deni, 2013, "Wacana Korupsi dalam Karikatur pada Periode Pemerintahan Presiden Paska Reformasi di Kumpulan Karikatur "dari Presiden ke Presiden Edisi Tingkah-Polah Elit Politik". Jurnal Unair. Volume 2, No. 2.

Moleong, Lexy J. 2014. Metodologi Penelitian Kualitatif. Bandung: PT Remaja Rosdakarya.

Mulyana. 2005. Kajian Wacana Teori, Metode, dan Aplikasi Prinsip-Prinsip Analisis Wacana. Yogyakarta: Tiara Wacana.

Sobur, Alex. 2013. Semiotika Komunikasi. Bandung: PT Remaja Rosdakarya. 
Subroto, Edi. 2011. Pengantar Studi Semantik dan Pragmatik (Buku 1. Pengantar Studi Semantik). Surakarta: Cakrawala Media.

Sudaryanto. 2015. Metode dan Aneka Teknik Analisis Bahasa. Yogyakarta: Duta Wacana University Press.

Sukmadinata, Nana Syaodih. 2009. Metode Penelitian Pendidikan. Bandung: PT Remaja Rosdakarya.

Wijana, I Dewa Putu. 2004. Kartun: Studi tentang Permainan Bahasa. Yogyakarta: Ombak Publishing. 